1. $\underline{\text { Home }}$

2. Journals

3. International Journal of Social Economics

4. Volume 48 Issue 11

5. Trade openness channels and labour market performance: evidence from Nigeria

\title{
Trade openness channels and labour market performance: evidence from Nigeria
}

Abiola John_Asaleye__Joseph Olufemi_Ogunjobi__Omotola Adedoyin_Ezenwoke International Journal of Social Economics

ISSN: 0306-8293

Article publication date: 14 July 2021 \& Reprints \& Permissions

Issue publication date: 27 October 2021

DOWNLOADS

\section{Abstract}

Purpose

The implications of trade on developing economies have generated substantial debates with most studies focussed on "openness in the policy". Hence, the purpose of this study is to focus on "openness in practice".

Design/methodology/approach

This study uses two models and employed the vector error correction model and structural vector autoregression, first, to examine the sectoral effects; second, to investigate the efficacy of neoclassical and new trade theories; and third, to analyse the effect of trade openness shock on Nigerian labour market performance.

Findings

The results of the first model showed that trade openness has an adverse effect on employment and wages in both the agriculture and manufacturing 
sectors. Likewise, the study concludes that the new trade theory explains trade's behaviour on employment and wages in Nigeria. The second model showed that the effect of error shock from trade openness affected wages more than employment.

Research limitations/implications

The study ignores the distributional effects due to unavailability of data.

Practical implications

The study suggested, amongst others, the need for policies mix on the labour market via a coherent set of initiatives in other to increase the competitiveness of Nigeria in the international market.

Originality/value

Most studies focussed on openness in policy through the channels identified in the literature. However, this study investigates these channels in "openness in practice" and investigates trade theories' efficacy on manufacturing and agricultural sectors in Nigeria, which has been neglected in the literature.

\section{Keywords}

- Trade openness

- Wages

- Employment

- VAR

- Nigeria

- $\mathrm{C} 3$

- $\mathrm{F} 6$

- $\mathrm{J} 21$

- J64

\section{Citation}

Asaleye, A.J., Ogunjobi, J.O. and Ezenwoke, O.A. (2021), "Trade openness channels and labour market performance: evidence from Nigeria", International Journal of Social Economics, Vol. 48 No. 11, pp. 1589-

1607. https://doi.org/10.1108/IJSE-06-2018-0320

Download as .RIS 


\section{Publisher \\ Emerald Publishing Limited \\ Copyright $\odot$ 2021, Emerald Publishing Limited \\ 2021 Emerald Publishing Limited}

